\title{
MEMORIUM A Road to Learning With a Character as Noble as an Orchid and a Career as Steady as a Pine Tree
} \author{
and Adarsh Kumar ${ }^{1}$ \\ ${ }^{1}$ The Tsim Tsoum Institute, Ul. Golebia 2, 31-007, Krakow, Poland \\ ${ }^{2}$ International College of Nutrition, Moradabad, India \\ ${ }^{3}$ International College of Cardiology, Kosice, Slovakia
}

RB Singh ${ }^{1,2,3, *}$, TK Basu ${ }^{1}$, SS Rastogi ${ }^{1}$, SN Acharya ${ }^{1}$, LR Juneja $^{1}$, Daniel Pella ${ }^{1}$, Min Chin ${ }^{1}$

Dr Zhu Shoumin was a steadfast friend who believed in the warmth of friendship. Zhu gave his all to those that knew him. He was a shining light that guided us with his happy enthusiasm, visionary NUTRIOLOGICAL thinking and his exemplary work ethos and energy. In the last 30 years, he coauthored important classic article that have been published in the international journals and he made contributions to presentations in India, UK, Canada. We will always think of him as a great friend and his parting is a great loss. We in the International College of Nutrition knew him for the last 30 years, planned great adventures with him in India and China as well as in Canada on Cardiovascular Diseases and somehow these should be kept alive. He organised the 5th World Congress on Clinical Nutrition at Zhejiang Medical University, Hangzhou, China in 1995 which is unforgettable.

For members of the International College of Nutrition worldwide, including Indian and Canadian friends, Zhu Shoumin remains an integral part of what we do. After China, India was his second country, where he enthusiastically described the role of Konjac food in cardiovascular diseases. His real home, of course, was and remains worldwide and beyond, the sphere of the human mind, what Edouard Le Roy, Pierre Teilhard de Chardin and above all Vladimir Ivanovich Vernadsky called the noösphere, the sphere of human creativity, complementing Eduard Suess's (the Viennese geophysist) biosphere. Zhu helped takeing us a step beyond the noösphere by examining both the basic rules and their applications emphasizes the role of foods rather than nutrients, in the prevention of chronic diseases in 1990.These were steps toward introducing nutrients into Nutrition Science when he brought us the idea of foods. By seeking new approach to quantitatively assess the role of foods with otherwise qualitative nutrients, we can prevent diseases in a broader view by preventing CVDs we also prevent type 2 diabetes mellitus and brain degeneration by this functional food approach. By this idea and approach, Zhu Shoumin acted like Confucius as well as as like Hippocrates, which had

*Address correspondence to this author at the The Tsim Tsoum Institute, Ul. Golebia 2, 31-007, Krakow, Poland; Tel: 0091591 2417437;

E-mail: rbs@tsimtsoum.net similarity with great physicians of India like Sushruta and Charak of the 5th century BCE. In classical Greek, "noos" and "nous" both describe the human mind; the Attic Greek "nous" serves to portmanteau it into "chronos", time, and "sphairos", sphere, into a chronousphere. On the basic side, Zhu,s enthusiasm and his stamina supporting his inquiry into the unknown laid the basis of FOOD-MIND-BODY approach via pineal-hypothalamic-pituitary-adrenal-cellular network first and in the cosmos next. His last contributions were data for examining the role of the natural herbs in modulating human blood pressure. Shoumin showed that the same dose of the same food can enhance or delay the development of a risk factor, depending upon the content of the nutrients. He contributed many research articles on Nutrition in Cardiovascular Diseases. His publications assure him a lasting place in science and health care through which he will continue to contribute for time to come.

We appreciate Dr Min Chin and Ms Zhu Ying, zhhq1997@163.com, Shoumin,s daughter for providing further details about the achievements of Dr Zhu Shoumin.

ZHU Shoumin, a renowned biochemist and professor of nutrition, was born into a family of traditional Chinese medicine in Shaoxing, Zhejiang Province. In 1948, he graduated from the Department of Agricultural Chemistry in Zhejiang University and completed his graduate program of Biochemistry in Shanghai Medical Institute in 1951. He wass a student of Professor LUO Dengyi in Zhejiang University and Professor LIN Guohao in Shanghai Medical Institute, both of them being biochemical nutritionists. Following his teachers' instructions, he has been earnestly engaged in teaching and research work in biochemical nutrition from his graduation up to now.

In 1951, he became successively a teacher, a lecturer, an associate professor and a professor of biochemistry in Zhejiang Medical Institute (later named Zhejiang Medical University and now merged into Zhejiang University). In 1984, Zhejiang Medical University was preparing to establish the first specialty in medical nutrition in China. The university enrolled its first five-year undergraduate students in the following year in 1985 and ZHU Shoumin was appointed the Chair of the department. In 1990, Zhejiang 
Medical University (China Institute of Medical Science Zhejiang Branch) created the Center for Nutrition and Food Research and he has been the Director ever since. He was a visiting professor of Miami University and was nominated as Honorary professor of International College of Nutrition. He has been in-charge of the establishment of Zhejiang Nutrition Academy and has been its Chairman. He used to take up leading positions in a number of academic organizations. For instance, he used to be the Deputy Chairman and Chairman of International Nutrition Academy and he was a full member of management in the Academy. Also, he agreed to established the Zhu Shoumin Award at the request of president and executive director, to encourage young professionals under International College of Nutrition. He has been given Singh,s falicitation award by the International College of Nutrition. He was awarded fellowships of the International College of Nutrition and International College of Cardiology.

In 1985, Professor ZHU Shoumin wrote "Q \& A on Food and Nutrition for Seniors" and CHEN Yun, a late state leader, contributed his calligraphy for the title of the book. His assiduous work has produced many achievements, including over 100 academic papers at home and abroad, and over 30 books (working as editor-in-chief, deputy editor-inchief and co-editor). He has also been an editing and supervising members for medical textbooks for institutions of advanced learning sent to the Ministry of Health. On September 10, 1996 (the Teachers' Day), he got the honor of meeting and taking photos with President JIANG Zemin and other state leaders in the People's Conference Hall in Beijing. He has been conferred the title of Model Worker of the national education sector; he also enjoys the special subsidy by the State Council and has repeatedly been granted awards for his outstanding work by the State Council, the State Scientific and Technological Commission, the State Education Commission, National Population and Family Planning Commission, Ministry of Health, People's Government of Zhejiang Province and People's Government of Hangzhou City.

Accomplished in biological statistics and experiment design, Professor ZHU has long been engaged in the scientific research and product development in biochemistry and nutrition. Wahaha Children's Nutritional Drink, a product developed by Professor ZHU, has won remarkable social and economical benefit and the Wahaha Company has, therefore, evolved from a small school-run company to a leader in Chinese food industry. Professor ZHU has also been awarded the $2^{\text {nd }}$ Prize of the State Touch Plan (the highest prize ever received by the Food Sector). Apart from that, other products developed by Professor ZHU, such as the "Shoumin Brand" Protein Powder (Patent No. ZL 031 42130.X) and Lanhaixing Healthy Balance Salt, have also been well sold.

In recent years, he has been engaged in the research of food for medical purposes and has acquired a number of patents. Patent No. ZL 91104669.0 is a liquid food (for hospital patients) processed from natural food sources and it has been ranked among the 100 technological items for promotion by Ministry of Health in the coming 10 years, as well as an item of state technological innovation. His latest patents include ZL 031 42130.X Solidified Full Nutrition Liquid Food and its method of manufacturing, patent No. ZL 03150631.3 and international patent No. A23L1/29 the manufacturing method of Full Nutrition Liquid Food for diabetics, patent No. ZL 20051 0049274.0, extraction method of anthocyanins of black rice.

Shoumin Medical Food Co. was established in 2003 by the Science and Technology Park of Zhejiang University. With an aim to promote the development of nutrition and medical food, the company has been expanding and has also won the support of Innovation Fund of Medium or Small Science and Technology Enterprises subjected to Ministry of Science and Technology. High purity and low cost anthocyanins of black rice has been recognized as a project by Innovation Fund of Medium or Small Science and Technology Enterprises subjected to Ministry of Science and Technology. At the end of the year 2004, Professor ZHU Shoumin delivered an academic report concerning medical food in China at the $10^{\text {th }}$ World Congress on Clinical Nutrition held in Thailand. Developments in this area will greatly facilitate the initiation of medical food in China and enhance the adoption of international practices.

(C) Singh et al.; Licensee Bentham Open.

This is an open access article licensed under the terms of the Creative Commons Attribution Non-Commercial License (http://creativecommons. org/licenses/ by-nc/3. 0/) which permits unrestricted, non-commercial use, distribution and reproduction in any medium, provided the work is properly cited. 